\title{
Технические науки
}

УАK 004.77 (англ)

Ван Тяньхан, Чэнь Чунью, ^и Аунвей, Ци Цзяхуэй, Ши Аей, ^ю Чан

Хэйлунцзянский сельско-хозяйственный университет Байи

Аацин, пров. Хэйлунцзян, Китай

\section{Исследование архитектуры и основных технологий облачной печати кампуса университета}

\begin{abstract}
После проведения анализа методов печати, используемых на территории кампуса, были выявлены проблемы при распечатке Аокументов студентами университета во время пиковой нагрузки. В то же время на территории кампуса существует проблема простоя оборудования в точках печати, за исключением периодов пиковой нагрузки. Вышеописанное Аает возможность внеАрения системы облачной печати на кампусе. При использовании облачной печати необходимость в традиционной печати отпаАает, при этом эффективность работы значительно возрастает и уменьшаются затраты на энергообеспечение. С уменьшением затрат на энергообеспечение у университета появилась возможность модернизации парка полиграфического оборудования. Результатом проведения исследования архитектуры системы услуг облачной печати, а также анализа основных ее технологий и Аругих аспектов использования стала описанная в Аанной статье модель, которая может быть применена Аля созАания системы поААержки облачной печати на кампусе.
\end{abstract}

Ключевые слова и словосочетания: облачная печать на кампусе; система услуг облачной печати; основные технологии облачной печати.

Wang Tianhang, Chen Chunyu, Li Dongwei, Qi Jiahui, Shi Lei, Liu Chang

Heilongjiang Bayi Agricultural University

China. Daqing, Heilongjiang

\section{Research the Architecture and Key Technologies of Cloud Printing on Campus}

\begin{abstract}
Through analyzing the present situation of campus print combing, found college students print peak is observable. While in the campus, there are problems such as the print shop has the idle print resources except the printing peak. This is an opportunity for campus cloud printing. Cloud printing subverts traditional printing patterns, greatly improving work efficiency and reducing consumption costs. Reduce the consumption cost has brought a new opportunity for the development of University printing market. Through the research on the architecture and cloud print service system, campus cloud print key technique analysis and other aspects of the campus cloud printing technology support model described, can be used as a push to support the campus practice cloud printing technology.
\end{abstract}

Keywords: campus cloud printing; cloud printing service system; key technology for cloud printing.

\section{Introduction}

With the rapid development of personal and commercial printing applications, Web personalization, diversification of print on demand is more and more obvious, and the main way to print or to the local print based, network printing has also appeared mostly for the local area network, or provide specific manufacturers based on print printing equipment, printing type, the lack of implementation of the Internet environment the 
seamless, universal print sharing and collaboration technology, need combined with advanced intelligent management technology and embedded technology, combined with the rapid increase in print resources, users print process, intelligent and networked. Early put forward the "cloud print" concept and action are the "Google cloud print" and "HP cloud printing system, they were on cloud printing technology development and layout, but did not form a unified standard system of.2010 in April, Google Cloud Print almost In the same year, in November of November, HP released cloud printing technology (HP ePrint), through the terminal device to send the mail to the cloud printer's unique E-mail address, the cloud printing function. Can be realized by Chrome in the same year in November.

At present, with the number of college students increased year by year, the number of students for printing is also increasing. The limitations of traditional print allow students to bring a series of problems in printing. College students usually print documents for homework, review papers, and all kinds of planning, analysis from the different departments and all kinds of community activities, a the most prominent feature of the students when printing is highly concentrated, generally concentrated in the campus students during the period of community defense, at the end of the review period, during the graduation thesis. In a university in Heilongjiang as an example, the number of colleges and universities in the scale of about 16000 people, the number around the campus and the surrounding print shop is only more than 10 , because the university a large number of students, teachers, students of print significantly, leading students in the queue waiting to take a print and spend a long time. But some students according to print Type compatibility and other issues facing the layout problem, site layout to enable students to spend longer time, which leads to the lower efficiency of printing; according to the print shop owner reflects, as the print peak students in the face of printing problems when employee is difficult to take into account all the needs of the students, resulting in processing print longer. But through the investigation. The four print shop, we found that the non-peak appeared idle, a large number of print resources idle phenomenon. Therefore campus cloud print is essential a printed form change.

\section{The concept and advantages of campus cloud printing}

2.1. Concepts of campus cloud printing

How to identify cloud print, no industry and academia formed a unified understanding. In this paper, the definition of Cloud Print tends to Internet based, integrated printing equipment resources, construction of roaming printer sharing platform, provides print services whenever and wherever possible the standard for the whole society. Under the background of the mobile Internet era, combined with electronic the current business model of maturity is very high. "cloud print" may become an important model for future printing services.

Cloud print is a combination of cloud print server based on embedded system, advanced network technology and cloud print service platform, let the user needs and resources for immediate release set print resource provider in the cloud printing platform intelligent fast matching, to form a new pattern of network printing. Cloud print in the cloud manufacturing theory and framework, research and application network printing technology, with "ondemand service" as the core concept, support different terminals on the set of resources 
virtualization access control, will print the set of resources sharing, will analyze the print task coordination, connect with the print server print resources across the region, many types of sets, with Cloud Print Service platform for the matching center. A unified, centralized intelligent management and operation, is a type of service oriented network, high efficiency and low energy consumption, convenient printing new models and technologies.

2.2. Advantages of campus cloud printing

(1) Convenience. Based on the convenience and popularity of the Internet, cloud printing can make students no longer subject to the constraints of time and place, enjoy services anytime and anywhere, respond to users' needs faster, and improve working efficiency.

(2) timesaver. Cloud print mode combined with the print shop to print can be flexible to cope with multiple user requests in the shortest possible time of the request for receiving and processing. Users can print shop on the platform to understand the real-time status of - busy or idle, attended by the selection of the appropriate print shop to print on demand for their own. In advance of the print file upload to the print platform, greatly reduce the waiting queue problems facing the peak of the traditional print mode, facing the print business busy period in the print shop, cloud printing platform using the new mode of print online and offline pickup users can reduce a lot of unnecessary time consuming.

(3) Depending on the students' consumption habits. College students because of consumption ability and economic source restrictions in the consumer more pursuit of "high quality and inexpensive" products. At the same time, students at the forefront of the times, the novelty have a keen grasp and higher acceptability. Cloud print mode implemented in the University in accordance with the students"s consumption concepts and habits, can quickly integrate into the consumption behavior of college students.

4) Social benefits: Cloud printing may reshape the traditional printing industry, printing can be different from the traditional form of an effective cloud printing industry, have a strong social utility and economic value. Internet information technology, users can be on the platform according to the state of online printing equipment using effective reservation, avoid peak print on the one hand, convenient for users, on the other hand print businesses also make full use of idle equipment, improve the printing efficiency of printing equipment.

\section{Research and architecture of cloud printing service system}

3.1. Cloud printing systems

According to the cloud print service platform meaning presents a multi user oriented, to provide cloud printing business application system of group and individual private applications, as showed in Figure 1. The cloud printing system in the cloud service provider (Cloud Service, Provider, CSP), the cloud service consumer (CloudService Custom, CSC and cloud resource provider (CloudRecourseProvider), CRP). Cloud resource providers will print resources and print ability to upload to the cloud print service platform; customers through various terminals will cloud print service platform print job released to cloud service providers, cloud services in the integrated management of technology, geographic information system Geographic Information System, GIS) and service level (application service quality agreement agreement, SLA) technology support, print and print resources demand, combined with the request of his service to complete printing needs Cycle. 


\subsection{Cloud Print overall architecture}

The research and development of cloud printer system, commercial trial and promotion is a comprehensive process, many of the major technical problems to be resolved. Cloud printing architecture is by analyzing the implementation and demand of printing industry vertical structure on the platform service-level and practical application in the design and development of 9 , preliminary planning of cloud the print service platform architecture. The comprehensive network print, the progress status of cloud manufacturing service platform 10-11 cloud print service platform and meaning, put forward the cloud print service system architecture. As showed in Figure 1.

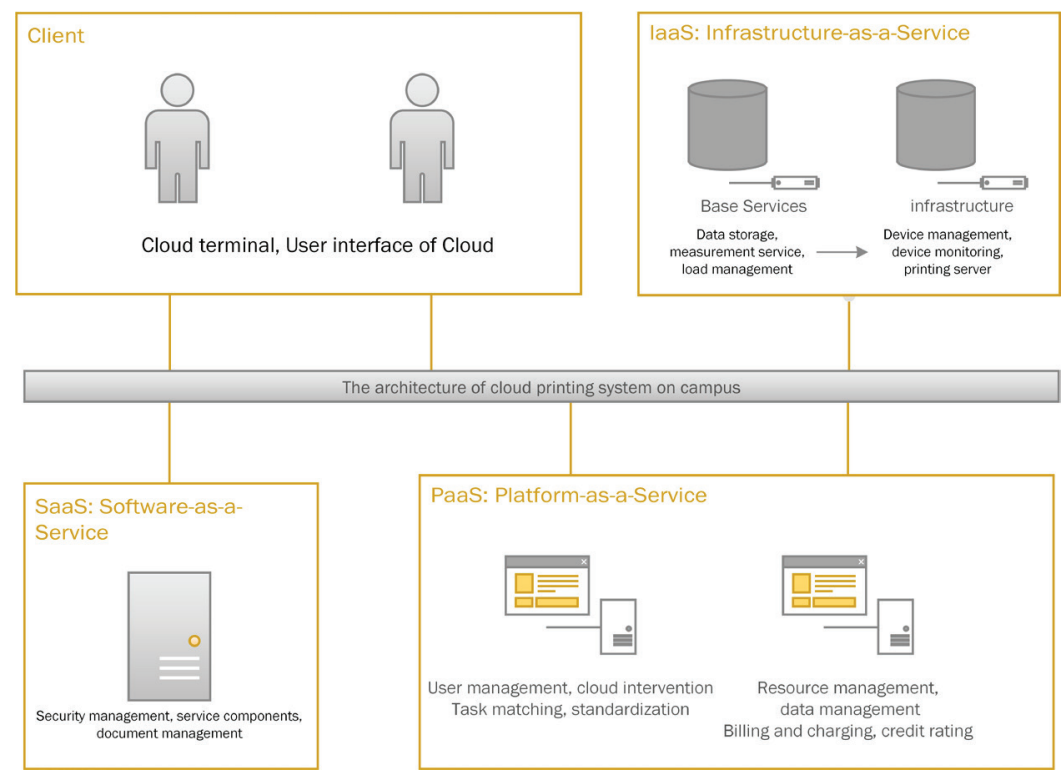

Pic. 1. The architecture of cloud printing system on campus

The architecture mainly comprises the following five levels.

(1) The structure platform environment layer: mainly provides database, cloud print service platform of software protection, the original framework, platform and provide the support module, data monitoring and other functions, and the client software platform layer, service layer, service layer, service layer provides a series of infrastructure resources to support normal operation.

(2) Client Layer provides user registration, support access and use of Cloud Print platform technology. Users can use the B/S structure (Browser/Server) or C/S (Client / Server) and different ways of registration, access and use of cloud print system platform for immediate release print demand, the duty cycle of the whole process of visualization, participation in industry evaluation, rapid response to change tasks and other functions.

(3) The layer of Software-as-a-Service: software service layer business model block and service component block intermediate conversion layer for business users set. Based on the analysis of task demands provide users in different industries on the establishment of different particle sizes and the actual demand and service module match, can quickly respond to business model call different. 
(4) The layer of Infrastructure-as-a-Service: layer of cloud service operators to provide user management, data management, resource provider pricing, billing charges and other services. All kinds of print resources in the service layer converged access network, through the cloud print service definition tool virtual resource encapsulation into distributed cloud resources, according to the user's need intelligent search, resource scheduling, task scheduling and other services. The degree of enhancement of Intelligent Cloud demand and cloud resources, track and record management, transaction process, and credit evaluation.

(5) The layer of Platform-as-a-Service: infrastructure layer service layer includes a variety of basic services and facilities. The basic resource layer, call for the diverse needs of users can publish through the unified registration, cloud components to form a standard interface. For printers and other hardware resources, the physical resources for access to the network, using the embedded cloud the print server model based on cloud access, print the tangible resources fully connected.

\section{Key technology of campus clouds printing}

(1) Access control technology: in order to satisfy different users and users to access different ways of printing platform, we need to develop strategies for diversification and multi terminal real-time management and control.

(2) Technology: cloud services, cloud print service matching technology is the main part of the implementation of cloud print, including resource set, task focused, analytical, etc., mainly including: task release, description, analysis, call monitoring, queue implementation technology, release, set of resources; the description of virtualization, call, monitoring, evaluation, and met the wrong adjustment, implementation; real-time tracking service directory, matching resources dynamic aggregation until the needs and resources.

(3) Cloud Resources Internet Technology: Internet technology is the general resource access platform cloud print printer technology. The main research important print resources through the embedded technology in the cloud printing platform deployment, network, registration, monitoring, including calling technology: support cloud printing terminal through the physical network connection means cloud print server the definition of cloud; terminal physical resource description, packaging, virtualization, application publishing technology; embedded cloud print server network protocol.

(4) Comprehensive application service technology: integrated application of cloud print service is a major factor in development of cloud print system. Mainly include: cloud printing market for the group's business, personal business process management and implementation steps respectively; cloud print service cost and pricing standard, operation strategy and payment platform technology; cloud print mode CSP, CSC, CRP these three characters and other service credit management mechanism.

\section{Conclusions}

Cloud print service platform is a product of the development of the Internet era, even if the cloud printing platform technology still has much room for improvement, there are some problems to be solved, but as the inevitable trend of the development of the times, the cloud platform also has great advantages. Only by optimizing the structure of the 
service platform, improve security, compatibility and other issues, can give users a better experience. Although the campus is to accept new things and new phenomena in the fastest region, but the research on campus cloud printing platform and the construction is a long-term arduous arduous task, we also need to study the optimization of many technical problems, the use of more mature business model, contribute to the rapid development of new print mode.

\title{
6. Acknowledgment
}

The paper was supported by Supported by Training Program of Innovation and Entrepreneurship for Undergraduates of province Heilongjiang (No.201610223052), Research project of Philosophy and Social Sciences inDaqing (№DSGB2017027), Teaching research project of Heilongjiang Bayi Agricultural University (№NDJY15Z13), Research Foundation for the Doctoral Program of Heilongjiang Bayi Agricultural University (№XDB2014-18).

1. Wang Lidong. Encrypted cloud Printing [J]. Digital Printing, 2010 (7): 66-68.

2. Cai Lili, Wang Jinhua. Money Hai Zhong, cloud printing system research on the key technology [J]. Journal of Jinling Institute of Technology, 2015 (09).

3. Yung Cheng Hsieh, Hung Sheng Lin. A Study of the Functionalities and Workflow for Webto-Print Platform [J]. Advanced Materials Research, 2010(174):151-154.

4. Jbaliga R, Ayre W, Hinton K., Green Cloud Computing: Balancing Energy in Processing. Storage and Transport [J]. Proceedings of IEEE, 2011, 99(1):149-167.

5. Sim K M. Agent-Based Cloud Computing [J]. IEEE Transactions on Services Computing, 2011,5(4):564-577.

6. Zeng Jun, Li Jun. Operations simulation as a Cloud Based Service [J]. IEEE Conference Anthology, 2013(2):1-5.

7. Han H, Kim S, Jung H. A Restful Approach to the management of Cloud Infrastructure [C]. Jersey: IEEE International Conference on Cloud Computing, 2009.

\author{
(C) Liu Chang, 2018 \\ (C) Wang Tianhang, 2018 \\ (C) Chen Chunyu, 2018 \\ (C) Li Dongwei, 2018 \\ (C) Qi Jiahui, 2018 \\ (C) Shi Lei, 2018
}

Для цитирования: Исследование архитектуры и основных технологий облачной печати кампуса университета / Лю Чан, Ван Тяньхан, Чэнь Чунью, Ли Дунвей, Ци Цзяхуэй, Ши Лей // Территория новых возможностей. Вестник Владивостокского государственного университета экономики и сервиса. 2018. Т. 10. № 1. С. 110-115.

For citation: Liu Chang, Wang Tianhang, Chen Chunyu, Li Dongwei, Qi Jiahui, Shi Lei. Research the Architecture and Key Technologies of Cloud Printing on Campus, The Territory of New Opportunities. The Herald of Vladivostok State University of Economics and Service, 2018, Vol. 10, No 1, pp. 110-115. DOI dx.doi.org/10.24866/VVSU/2073-3984/2018-1/110-115

Дата поступления: 10.12.2017. 